\title{
Prevalence of HBsAg and anti HCV Ab among patients with suspected acute viral hepatitis in baghdad, Iraq in 2010
}

\author{
Hanan Abdulghafoor Khaleel ${ }^{1 *}$, Atallah Mekhlef Turky ${ }^{2}$, Ahmed Samir Al-Naaimi ${ }^{3}$, Rasha Waleed Jalil ${ }^{4}$, Olah A. Mekhlef ${ }^{4}$, Susan Abdul \\ Kareem ${ }^{4}$, Nadia Yousif Hasan ${ }^{4}$ and Azhar Abdulla Dhadain ${ }^{4}$ \\ *Correspondence: hanan_azawy2000@yahoo.com \\ ${ }^{1}$ Viral Hepatitis Section, Communicable Disease Control Center, Public Health Directorate, Ministry of Health, Baghdad, Iraq. \\ ${ }^{2}$ Head of Viral Hepatitis Section, Communicable Disease Control Center, Public Health Directorate, Ministry of Health, Baghdad, Iraq. \\ ${ }^{3}$ Baghdad Medical college, Baghdad University, Baghdad, Iraq. \\ ${ }^{4}$ Central Public Health Laboratories, Public Health Directorate, Ministry of Health, Baghdad, Iraq.
}

\begin{abstract}
Background: Viral hepatitis is a preventable infectious disease with increasing importance all over the world. The aim of the current study is to assess the prevalence rate of acute viral hepatitis and positive viral hepatitis marker among clients of primary health care centers in Baghdad in 2010. In addition, to assess the proportion of positive hepatitis B and C viral marker from the total suspected acute viral hepatitis cases. Moreover, to determine the contribution of selected explanatory variables to the risk of testing positive for $\mathrm{HBV}$ and HCV serum markers.

Methods: A descriptive cross sectional study were carried out at the primary health care centers in Baghdad over 1 year. A questionnaire form was used to collect data about demographic factors and the results of the investigations. Total serum bilirubin and bilirubin in urine were done at the primary health care center laboratory. The rest of the sera samples were sent to Hepatitis referral Lab at Central Public Health Laboratory (CPHL) to be tested for HBs Ag and anti HCV using ELISA technique.

Results: A total of 7,576,372 consultations to primary health care centers were recorded in Baghdad during 1 year in 2010. Among those a total of 2,692 cases ( 35.5 per 100,000 consultations) were labeled as acute viral hepatitis cases. Only (3.3\%) of cases were positive for HBs Ag and another $0.7 \%$ had positive anti-HCV antibodies.

Conclusion: Proportion of HBs Ag positive tests among suspected acute cases was intermediate. The only predictor for positive HBs Ag was age while controlling for other risk factors. Proportion of Anti HCV positive tests among suspected cases was low. History of blood transfusion and previous tattooing or cupping were the most powerful predictors of Anti HCV positivity while controlling for all other risk factors.
\end{abstract}

Keywords: Hepatitis B, hepatitis C, prevalence, acute jaundice

\section{Introduction}

Globally, an estimated $78 \%$ of primary liver cancer and $57 \%$ of liver cirrhosis cases are caused by viral hepatitis, and 1 million deaths from viral hepatitis occur each year (DHHS, 2010). Approximately 350 million persons are infected with $\mathrm{HBV}$, and another 130-170 million are living with HCV infection (DHHS, 2010). According to a study done in 2005, Iraq is considered as a country of low endemicity for HBV and HCV because the prevalence of $\mathrm{HBs}$ Ag was $1.6 \%$ and that of Anti HCV Ab was $0.4 \%$ in general population (World Hepatitis Alliance, 2010). The aim of the current study is to assess the prevalence rate of acute viral hepatitis and positive viral hepatitis marker among clients of primary health care centers in Baghdad in 2010. In addition to assessment of the proportion of positive hepatitis $B$ and $C$ viral marker from the total cases with suspected acute viral hepatitis. Moreover, to determine the contribution of selected explanatory variables to the risk of testing positive for HBV and HCV serum markers.

\section{Literature review}

Hepatitis B virus (HBV) was first detected in 1970 following the identification of the Australian antigen [1]. HBV infection is an established cause of acute and chronic hepatitis. The clinical presentation of acute hepatitis B is similar to that of other types of acute viral hepatitis [2]. Acute HBV infection is anicteric in nearly $50 \%$ of adults, which explains the high positivity rate of serum markers in those who give no history of acute HBV infection [3]. While most acute HBV infections in adults result in complete recovery, fulminant hepatitis occurs in about $1 \%$ to $2 \%$ [2]. Most of the complications caused by $\mathrm{HBV}$ are due to chronic infection which occur in nearly $5 \%$ of acute adult cases [2].

In countries with low endemicity (HBs Ag prevalenceless than 2\%) most infections occur in young adults and especially among persons who are at high risk (horizontal transmission) while in higher and intermediate endemicity areas ( $\mathrm{HBs}$ Ag prevalence $>2 \%$ ) most infections occur as a result of perinatal transmission from HBs Ag-positive mothers (vertical transmission) or early horizontal transmission via close contact in the household family setting [4]. One of the most important strategies to prevent and control HBV is the administration of Hepatitis B Vaccine which has been found to be $80 \%$ to $100 \%$ effective 
Khaleel et al. Epidemiology Reports 2013,

in preventing infection in those who receive the complete course of vaccine [2].

Hepatitis C virus (HCV) had been identified in 1989 [1]. Less than $1 \%$ of HCV-infected patients present with an acute illness associated with jaundice [3]. The diagnosis of acute hepatitis $C$ is often difficult because there is no serological definition of acute hepatitis $C$, and because many individuals will not have had documentation of a previously negative anti-HCV test [3]. HCV is primarily transmitted through contact with infected blood $[5,6,7]$. HCV transmission also occurs through unsafe injection practices in health-care facilities and among intravenous drug abusers, from mother to child at the time of birth, and infrequently through sexual contact with an infected partner [6]. The development of serologic screening tests and other prevention strategies have contributed to a decline in HCV transmission [8].

Although there are distinct differences in many clinical aspects, general clinical features are common to all the viral hepatitides and characterized by prodromal, icteric and convalescence phase which is followed by chronicity in 5-10\% of adults infected with HBV and $80-85 \%$ of adults infected with HCV [3]. In Iraq, current diagnosis of acute hepatitis $B$ and acute Hepatitis $C$ is done by the detection of $\mathrm{HBsAg}$ and Anti HCV Ab in sera of patients with clinical signs and symptoms suggestive of acute viral hepatitis [9]. Strategies to prevent both infections are being applied by the majority of the institiutions; one of the most important strategies is Hepatitis B vaccine.

\section{Patients and methods Study population}

Baghdad is divided into 2 parts by Tigris River, Karkh is the southern part and Rusafa is the northern part. Each side is served by 7-8 primary health care sectors which is composed of 10-15 primary health care centers.

Patients attending the primary health care centers in Baghdad (Alrusafa and Alkarkh) with jaundice or signs and symptoms suggestive of acute viral hepatitis. Baghdad is the capital of Iraq with a high population density which approximately equals to 7716960 individuals in 2010, according to the annual statistical abstract released from Ministry of planning \& development cooperation, Central organization for statistics and information technology.

\section{Case definition of suspected acute viral hepatitis}

Patients with one of the following characteristics:

1)Acute clinical illness that includes malaise, extreme fa tigue, fever, anorexia, vomiting. Combined with right upper quadrant pain and dark urine.

2)Clinical jaundice and positive bile pigment in urine and elevated total serum bilirubin.

3)History of contact with an acute or known chronic case of viral hepatitis.

\section{Study sample}

All eligible subjects recorded during the one year study period extending from $15^{\text {th }}$ March 2010 to $15^{\text {th }}$ March 2011 were included in the study.

\section{Data collection}

A specially designed semi-structured questionnaire form was used to collect data about demographic factors like age, sex, and residence in addition to history of illness, possible risk factors and the results of the investigations.

Blood sample $(5-8 \mathrm{ml})$ was drawn from each patient and sera were separated at the primary health care center laboratory in each sector. Total serum bilirubin and bilirubin in urine were done at the primary health care center laboratory. The rest of the sera samples were sent to the Central Public Health Laboratory (CPHL) to be tested for HBs Ag and anti HCV Ab using ELISA technique at the reference laboratory for viral hepatitis.

\section{Ethical considerations}

The data collected for the purposes of current research were part of standard clinical practice of primary health care center when dealing with patients having jaundice or suspected to have hepatitis. Patient's privacy was secured and identifying information was kept confidential. Prompt treatment was provided for all study subjects.

\section{Statistical analysis}

Epi info v.3.5.1 was used to enter the data and statistical analysis was done using SPSS v13. Odds ratio was used to present the strength of association between 2 dichotomous variables. Chisquare test was used to assess the statistical significance of cross-tabulation for categorical variables. Discriminant analysis was used to adjust for confounding effect when assessing the contribution of a list of explanatory variables to the risk of testing positive for a viral marker. This statistical method was used instead of multiple logistic regression model that provides a more easily interpreted effect size indices, to override the need for making valid assumptions about normality of variables included in the model. The discriminant analysis calculates pooled within-groups correlation coefficients between discriminating variables and standardized canonical discriminant functions to rank the discriminating variables according to their discriminatory power between outcome categories. A forward selection algorithm using Wilks' lambda was adopted to select among a list of predictors, only those that provide important improvement to the discriminatory model. The unstandardized discriminant function coefficients were calculated for each discriminatory variable included in the model and included in the equation used to calculate discriminant score. A calculated discriminant score closer to its value at each group centroid was used to judge the predicted group membership of each study participant. P value less than 0.05 was considered statistically significant. 
Khaleel et al. Epidemiology Reports 2013,

Table 1. Prevalence of HBsAg and Anti HCV Ab in patients with acute jaundice attending primary health care centers in Baghdad in 2010.

\begin{tabular}{lccc}
\hline $\begin{array}{l}\text { Positive hepatitis marker } \\
\text { (n=2,692) }\end{array}$ & $\mathbf{N}$ & $\%$ & $\begin{array}{c}\text { 95\% confidence interval for } \\
\text { prevalence rate (\%) }\end{array}$ \\
\hline Anti-HCV antibodies & 19 & 0.7 & $(0.09$ to 2.5$)$ \\
HBs Antigen & 89 & 3.3 & $(1.6$ to 6$)$ \\
\hline
\end{tabular}

\section{Results}

A total of 7,576,372 consultations to primary health care centers were recorded in Baghdad. Among those a total of 2,692 cases (35.5 per 100,000 consultations) were labeled as suspected acute viral hepatitis cases. A positive hepatitis viral marker ( $A, B, C$ and $E$ ) was found in 1,332 cases (17.6 per 100,000 consultations) (table not presented), [10]. Only (3.3\%) of suspected cases with positive viral markers had HBs Ag and another $0.7 \%$ had positive anti-HCV antibodies in their tested sera, (Table 1).

Discriminant analysis was used to rank selected independent (explanatory) variables according to their capacity in predicting a specific positive viral hepatitis marker. It is a type of multivariate analysis, since the independent variables are entered together. The list of eligible predictors include: History of blood transfusion, History of tattoo or cupping, Age group, Past history of jaundice, History of chronic illness, Past Surgical History, Past history of Dentist visit, Primary Health Care Department (Alrusafa compared to Al-Karkh), History of jaundice in the contacts and Gender (male compared to female).

As shown in (Table 4), the predictors for positive serum anti$\mathrm{HCV}$ antibodies are ordered according to their importance in predicting positive cases. A negative sign for the coefficient indicates that the presence of this factor is associated with more probability for the tested subject being negative for this viral hepatitis marker, while a positive coefficient indicates increased probability of being a case. For example having a positive history of jaundice in contacts will reduce the probability of being positive for Anti HCV Ab, while the remaining variables when positive (or being a male or older age) increase the probability of being an Anti HCV Ab positive case.

From the list of 10 predictors used in the discriminant model only 3 were enough to yield a discriminant model which was able to predict positive anti-HCV with $42.1 \%$ accuracy and an overall prediction accuracy of $95.6 \%$. The predictive accuracy for the positive group is more important than that of the negative group, since the positive group represents a minority ( $<1 \%$ of the sample) and is not expected to affect the overall prediction accuracy. In addition the model is expected to screen for possible cases in the first place, (Table 5).

A positive history of blood transfusion was the most powerful predictor for positive HCV case followed by a history of tattoo or cupping followed by being older in age, (Table 2). When the values of these predictors are entered in the equation the discriminant score (D) is calculated. If the resulting $D$ score for a subject is higher than the critical value of 0.978 then we predict a positive HCV case, while a D score lower than the critical value predicts a negative HCV status. The more extreme is the calculated value of $D$ the higher our confidence in the prediction accuracy, (Table 5).

Of the studied risk factors, only increasing age was shown to increase the odds of testing positive for HBsAg (Table 3). As shown in (Table 6), the predictors for positive serum $\mathrm{HBs}$ Antigen are ordered according to their importance in predicting positive cases. A negative sign for the coefficient indicates that the presence of this factor is associated with more probability for the tested subject being negative for this viral hepatitis marker, while a positive coefficient indicates increased probability of being a case. For example having a positive history of jaundice in contacts will increase the probability of being positive for HBsAg. In the same way a positive value for the remaining variables when positive (or being a male or older age) increase the probability of being an HBsAg positive case.

From the list of 10 predictors used in the discriminant model only age was enough to yield a statistically significant discriminant model. The model had a zero predictive accuracy for positive HBs Antigen and $100 \%$ accuracy for negative group. The overall prediction accuracy of the model was $96.7 \%$. Although, the overall performance of the model based on age alone was very good, it was almost useless in predicting positive HBsAg. This is an important disadvantage, since such a model is expected to screen for possible cases in the first place, (Table 7).

When the value of age is entered in the equation the discriminant score (D) is calculated. If the resulting $D$ score for a subject is higher than the critical value of 0.307 then we predict a positive HBsAg case, while a D score lower than the critical value predicts a negative HBsAg status. The more extreme is the calculated value of $D$ the higher our confidence in the prediction accuracy. Based on the present model, one can exclude the presence of HBs antigen when age is $<15$ years with high confidence, while an age $15+$ will only increase the probability of having $\mathrm{HBsAg}$ with very low confidence, (Table 7).

\section{Discussion}

The aim of the current study was to determine the rate of new cases of hepatitis $B$ and $C$ in patients with suspected acute viral hepatitis in Baghdad in 2010. The prevalence of those two types were studied in 2005 and it was found to be $1.7 \%$ and $0.4 \%$ respectively [11].

Recent surveys suggest a shift in the HBV endemicity patterns in most Southern Mediterranean countries from high endemicity towards intermediate or low endemicity patterns [11]. It has been found that up to $30 \%$ of the population are $\mathrm{HBs}$ Ag positive in Africa and East Asia as well as in some parts of South America [1]. Several studies showed that the prevalence of HBs Ag in south Mediterranean countries is 
Khaleel et al. Epidemiology Reports 2013,

http://www.hoajonline.com/journals/pdf/2054-9911-1-1.pdf

Table 2. The odds of positive Anti HCV Ab by selected explanatory variables.

\begin{tabular}{|c|c|c|c|c|c|c|}
\hline & Total & & CV antibodies & & & \\
\hline & $\mathrm{N}$ & $\mathrm{N}$ & $\%$ & OR & $95 \% \mathrm{CI}$ for OR & $\mathrm{P}$ \\
\hline \multicolumn{7}{|c|}{ Primary Health Care Department } \\
\hline Alkarkh & 1199 & 5 & 0.4 & Reference & & \\
\hline Alrusafa & 1493 & 14 & 0.9 & 2.26 & $(0.81-6.29)$ & 0.109 \\
\hline \multicolumn{7}{|l|}{ Age groups } \\
\hline less than 15 yrs & 1592 & 2 & 0.01 & Reference & & \\
\hline $15-44 \mathrm{yrs}$ & 981 & 13 & 1.3 & 10.68 & $(2.4-47.41)$ & $<0.001$ \\
\hline more than 45 yrs & 116 & 4 & 3.4 & 28.39 & $(5.14-156.69)$ & $<0.001$ \\
\hline \multicolumn{7}{|l|}{ Gender } \\
\hline Female & 1223 & 6 & 0.5 & Reference & & \\
\hline male & 1466 & 13 & 0.9 & 1.81 & $(0.69-4.79)$ & 0.222 \\
\hline \multicolumn{7}{|c|}{ Past history of jaundice } \\
\hline Negative & 2315 & 12 & 0.5 & Reference & & \\
\hline Positive & 329 & 7 & 2.1 & 4.17 & $(1.63-10.67)$ & 0.001 \\
\hline \multicolumn{7}{|c|}{ History of jaundice in the contacts } \\
\hline Negative & 2105 & 18 & 0.9 & Reference & & \\
\hline Positive & 565 & 1 & 0.2 & 0.21 & $(0.03-1.54)$ & 0.089 \\
\hline \multicolumn{7}{|c|}{ History of blood transfusion } \\
\hline Negative & 2609 & 15 & 0.6 & Reference & & \\
\hline Positive & 59 & 4 & 6.8 & 12.58 & $(4.04-39.12)$ & $<0.001$ \\
\hline \multicolumn{7}{|c|}{ History of chronic illness } \\
\hline Negative & 2576 & 16 & 0.6 & Reference & & \\
\hline Positive & 93 & 3 & 3.2 & 5.33 & $(1.53-18.63)$ & 0.003 \\
\hline \multicolumn{7}{|c|}{ Past Surgical History } \\
\hline Negative & 2443 & 14 & 0.6 & Reference & & \\
\hline Positive & 223 & 5 & 2.2 & 3.98 & $(1.42-11.15)$ & 0.005 \\
\hline \multicolumn{7}{|c|}{ History of tattoo or cupping } \\
\hline Negative & 2602 & 15 & 0.6 & Reference & & \\
\hline Positive & 67 & 4 & 6 & 10.95 & $(3.53-33.93)$ & $<0.001$ \\
\hline \multicolumn{7}{|c|}{ History of subcutaneous, IM or IV injections } \\
\hline Negative & 2532 & 14 & 0.6 & Reference & & \\
\hline Positive & 134 & 5 & 3.7 & 6.97 & $(2.47-19.65)$ & $<0.001$ \\
\hline \multicolumn{7}{|c|}{ Past history of Dentist visit } \\
\hline Negative & 2214 & 12 & 0.5 & Reference & & \\
\hline Positive & 437 & 6 & 1.4 & 2.55 & $(0.95-6.84)$ & 0.053 \\
\hline
\end{tabular}

variable, that is, in Egypt it was 1.3\% among potentially healthy blood donors [12]; in Libya, it was 2.2\% [13]; in Tunisia, HBs Ag seropositivity ranged from $3 \%$ to $13 \%$ with higher prevalence in the south and central west regions [11]); in Algeria, it was 3.3\% [14]; in Morocco, some studies showed the prevalence of $\mathrm{HBsAg}$ among hemodialysis patients is $2 \%$ [15]. In Iran, studies showed that the prevalence of HBV infection rate reported in $15-39$ years, was $1.8 \%$ and in $40-69$ years, was $2.8 \%$ [16]. Another study done in Iran in 2006 to find the prevalence of $\mathrm{HBs}$ Ag showed that it was 2.6\% [17]. Turkey is considered of intermediate - high endemicity as shown by $8.2 \%$ and $6.2 \%$ prevalence of $\mathrm{HBs} \mathrm{Ag}$ in rural and urban areas respectively [18]. In Saudi Arabia, prevalence of $\mathrm{HBs}$ Ag ranges from 7.4\%$17 \%$ [19]. In UAE, the HBV prevalence ranges from 2-5\% [20]. 
Khaleel et al. Epidemiology Reports 2013,

Table 3. The odds of positive HBsAg by selected explanatory variables.

\begin{tabular}{|c|c|c|c|c|c|c|}
\hline & \multirow{2}{*}{$\frac{\text { Total }}{\mathrm{N}}$} & \multicolumn{2}{|c|}{ HBs Antigen } & \multirow[b]{2}{*}{ OR } & \multirow[b]{2}{*}{$95 \%$ CI for OR } & \multirow[b]{2}{*}{$\mathrm{P}$} \\
\hline & & $\mathrm{N}$ & $\%$ & & & \\
\hline \multicolumn{7}{|c|}{ Primary Health Care Department } \\
\hline Alkarkh & 1199 & 34 & 2.8 & Reference & & \\
\hline Alrusafa & 1493 & 55 & 3.7 & 1.31 & $(0.85-2.02)$ & 0.221 \\
\hline \multicolumn{7}{|l|}{ Age groups } \\
\hline less than 15 yrs & 1592 & 23 & 1.4 & Reference & & \\
\hline $15-44$ yrs & 981 & 52 & 5.3 & 3.82 & $(2.32-6.28)$ & $<0.001$ \\
\hline more than 45 yrs & 116 & 14 & 12.1 & 9.36 & $(4.68-18.74)$ & $<0.001$ \\
\hline \multicolumn{7}{|l|}{ Gender } \\
\hline Female & 1223 & 41 & 3.4 & Reference & & \\
\hline male & 1466 & 48 & 3.3 & 0.98 & $(0.64-1.49)$ & 0.91 \\
\hline \multicolumn{7}{|c|}{ Past history of jaundice } \\
\hline Negative & 2315 & 75 & 3.2 & Reference & & \\
\hline Positive & 329 & 12 & 3.6 & 1.13 & $(0.61-2.1)$ & 0.698 \\
\hline \multicolumn{7}{|c|}{ History of jaundice in the contacts } \\
\hline Negative & 2105 & 63 & 3 & Reference & & \\
\hline Positive & 565 & 25 & 4.4 & 1.5 & $(0.94-2.41)$ & 0.09 \\
\hline \multicolumn{7}{|c|}{ History of blood transfusion } \\
\hline Negative & 2609 & 83 & 3.2 & Reference & & \\
\hline Positive & 59 & 4 & 6.8 & 2.21 & $(0.78-6.25)$ & 0.124 \\
\hline \multicolumn{7}{|c|}{ History of chronic illness } \\
\hline Negative & 2576 & 82 & 3.2 & Reference & & \\
\hline Positive & 93 & 6 & 6.5 & 2.1 & $(0.89-4.94)$ & 0.083 \\
\hline \multicolumn{7}{|c|}{ Past Surgical History } \\
\hline Negative & 2443 & 78 & 3.2 & Reference & & \\
\hline Positive & 223 & 10 & 4.5 & 1.42 & $(0.73-2.79)$ & 0.301 \\
\hline \multicolumn{7}{|c|}{ History of tattoo or cupping } \\
\hline Negative & 2602 & 85 & 3.3 & Reference & & \\
\hline Positive & 67 & 3 & 4.5 & 1.39 & $(0.43-4.51)$ & 0.584 \\
\hline \multicolumn{7}{|c|}{ History of subcutaneous, IM or IV injections } \\
\hline Negative & 2532 & 80 & 3.2 & Reference & & \\
\hline Positive & 134 & 8 & 6 & 1.95 & $(0.92-4.11)$ & 0.076 \\
\hline \multicolumn{7}{|c|}{ Past history of Dentist visit } \\
\hline Negative & 2214 & 67 & 3 & Reference & & \\
\hline Positive & 437 & 21 & 4.8 & 1.62 & $(0.98-2.67)$ & 0.058 \\
\hline
\end{tabular}

In Syria, the overall prevalence rate for hepatitis B was $5.62 \%$ as shown by a study done in 2004 [21].

Most of these surveys depend on the prevalence of hepatitis B in the population. Determining the incidence of acute hepatitis $B$ is mainly limited by its asymptomatic clinical course and unreported patients who attend the private sector. In the current study, prevalence of HBs Ag in patients with signs and symptoms suggestive of acute viral hepatitis and who attended the primary health care centers in Baghdad was $(3.3 \%, 95 \% \mathrm{Cl}=1.6-6)$. However, the rate of acute viral hepatitis B in the yearly report in 2010 was $2.1 \%$ [22]. This difference may be attributed to the fact the period of the study was from March 2010 to March 2011 while the annual report which depends on the monthly reports of the primary health care institutions usually included the period extending from January 2010 to January 2011. Furthermore, the research included data only from primary health care centers that is the data from hospitals in regard to patients with acute viral 
Khaleel et al. Epidemiology Reports 2013,

http://www.hoajonline.com/journals/pdf/2054-9911-1-1.pdf

doi: 10.7243/2054-9911-1-1

Table 4. Discriminant analysis model with selected independent variables and results of serum anti-HCV antibodies test as the dependent variables.

\begin{tabular}{ll}
\hline Predictors & Coefficient \\
\hline History of blood transfusion & 0.661 \\
History of tattoo or cupping & 0.59 \\
Age group & 0.456 \\
Past history of jaundice & 0.377 \\
History of chronic illness & 0.336 \\
Past Surgical History & 0.245 \\
Past history of Dentist visit & 0.213 \\
Primary Health Care Department & 0.203 \\
History of jaundice in the contacts & -0.177 \\
Gender & 0.166 \\
\hline
\end{tabular}

Note: ${ }^{\star}$ Coefficient: Pooled within-groups correlations between discriminating variables and standardized canonical discriminant functions.

Table 5. Forward selection method for Discriminant analysis model with selected independent variables and results of serum anti-HCV antibodies test as the dependent variables.

\begin{tabular}{ll}
\hline Selected independent variables & $\begin{array}{l}\text { Coefficients used } \\
\text { in the discriminant } \\
\text { equation }\end{array}$ \\
\hline $\begin{aligned} \text { Age groups (coded as } 1 \text { for }<5 \text { yrs, 2 for 5-14 yrs, 3 } \\
\text { for 15-44 yrs and } 4 \text { for } 45+\text { yrs) }\end{aligned}$ & 0.509 \\
History of blood transfusion & 4.594 \\
History of tattoo or cupping & 3.34 \\
(Constant) & -1.349 \\
\hline & $\begin{array}{l}\text { Discriminant score } \\
\text { at group centroids }\end{array}$ \\
\hline Negative Anti-HCV antibodies & -0.014 \\
Positive Anti-HCV antibodies & 1.97 \\
Critical value & 0.978 \\
\hline
\end{tabular}

$\mathrm{P}($ model $)<0.001$ Discriminant score $(\mathrm{D})=-1.349+[0.509 \mathrm{x}$ Age group (coded as 1 for $<5$ yrs, 2 for 5-14 yrs, 3 for 15-44 yrs and 4 for $45+$ yrs) $]+[4.594 \times$ History of blood transfusion (coded as 1 for positive and zero for negative) $]+[3.34 \mathrm{x}$ History of tattoo or cupping (coded as 1 for positive and zero for negative)]

Accuracy of prediction for negative test results $=96 \%$

Accuracy of prediction for Positive test results $=42.1 \%$

Overall Accuracy of prediction $=95.6 \%$

hepatitis who were admitted directly to the hospital without referral from primary health care centers were not included. In contrast the monthly reports included such data.

One of the important limitations in this study is that only HBs Ag was used in diagnosis of suspected cases of acute hepatitis $B$ infection, and the classification of acute hepatitis $B$ requires the detection of Anti $\mathrm{HBC} \operatorname{lgM}$ and Anti HBs Ab to differentiate acute from chronic cases. Moreover, patients who attended the private sector were not included. Of the suspected risk
Table 6. Discriminant analysis model with selected independent variables and results of serum HBs Antigen test as the dependent variables.

\begin{tabular}{ll}
\hline Predictors & Coefficient \\
\hline Age group & 0.93 \\
History of chronic illness & 0.287 \\
History of jaundice in the contacts & 0.256 \\
Past history of Dentist visit & 0.237 \\
Primary Health Care Department & 0.219 \\
Past Surgical History & 0.205 \\
History of blood transfusion & 0.149 \\
History of tattoo or cupping & 0.096 \\
Past history of jaundice & 0.08 \\
Gender & 0.025 \\
\hline
\end{tabular}

Note: ${ }^{\star}$ Coefficient: Pooled within-groups correlations between discriminating variables and standardized canonical discriminant functions.

Table 7. Forward selection method for Discriminant analysis model with selected independent variables and results of serum HBs Antigen test as the dependent variables.

\begin{tabular}{|c|c|}
\hline Selected independent variables & $\begin{array}{l}\text { Coefficients used in the } \\
\text { discriminant equation }\end{array}$ \\
\hline $\begin{array}{l}\text { Age group (coded as } 1 \text { for }<5 \text { yrs, } 2 \text { for } 5-14 \\
\text { yrs, } 3 \text { for } 15-44 \text { yrs and } 4 \text { for } \\
45+\text { yrs) }\end{array}$ & 1.299 \\
\hline (Constant) & -2.985 \\
\hline & $\begin{array}{l}\text { Discriminant score at } \\
\text { group centroids }\end{array}$ \\
\hline Negative HBs Antigen & -0.022 \\
\hline Positive HBs Antigen & 0.636 \\
\hline Critical value & 0.307 \\
\hline \multicolumn{2}{|c|}{$\begin{array}{l}\mathrm{P}(\text { model })<0.001 \text { Discriminant score }(\mathrm{D})=-2.985+[1.299 \times \text { Age } \\
\text { group }(\text { coded as } 1 \text { for }<5 \text { yrs, } 2 \text { for } 5-14 \text { yrs, } 3 \text { for } 15-44 \text { yrs and } 4 \text { for } \\
45+\text { yrs })] \text { Prediction accuracy for negative test results }=100 \% \\
\text { Prediction accuracy for Positive test results }=0 \% \\
\text { Overall prediction accuracy }=96.7 \%\end{array}$} \\
\hline
\end{tabular}

factors, only increasing age was significantly associated with increased odds of testing positive for $\mathrm{HBs}$ Ag. This might be explained by the fact that the introduction of Hepatitis $B$ vaccine in the national program of immunization in was in 1993 [23]. Moreover, viral hepatitis control and prevention program has started since early seventies and had put an essential, annually updated plan that conains important startegies to prevent and control certain types of viral hepatitis $(A, B, C, E$ and $D)[22]$. Long exposure in old individuals may be another important factor for the signifcant association between increasing age and positivity for $\mathrm{HBsAg}$. One of the strategies include screening for $\mathrm{HBs} \mathrm{Ag}$ in preoperative patients, pregnant women and renal dialysis patients and begin administration of hepatitis $B$ vaccine for those who 
Khaleel et al. Epidemiology Reports 2013,

test negative. In addition to the use of strict sterilization, isolated surgical equipments and separted dialysis machine for those who are positive for HBs Ag. Moreover, screening of all donated blood for $\mathrm{HBsAg}$ is another important startegy that helped to reduce the prevalence from $3.3 \%$ in early seventies to $1.7 \%$ in $2005[9,23]$.

In regard to Hepatitis $C$, it has been found that the proportion of persons living with (HCV) is greatest in Asia, sub-Saharan Africa, and Egypt [11]; HCV is responsible for infecting over 20 million in Arab countries [24]. In countries of the south Mediterranean region, the prevalence of HCV Abs was highest in Egypt (13\%) and accounts for $31 \%$ of acute viral hepatitis, in Libya (1.2\%), in Morocco (1.93\%), in Algeria (2.5\%), in Tunisia (0.4\%) [11]. In countries nearby Iraq, A 6.3 incidence rate [25] of HCV infection and $2.8 \%$ prevalence of HCV Abs was reported in the general population of Qatar [26]; the prevalence rate for anti HCV Abs was 2.8\% in Syria; in Iran it ranges between 0.5\%-1\% [20]; in Turkey (1.5\%) [20]; in Saudi Arabia, (6.3\%) [20]; in United Arab Emirates, the prevalence of anti-HCV antibodies was $23 \%$ while other references mentioned a prevalence of $0.8 \%$ [26].

Similarly to hepatitis $B$, studying the incidence of hepatitis $C$ is limited by the asymptomatic nature of the acute stage, the fact the used assays cannot differentiate acute from chronic cases, and lack of registration of patients who attend the private sector. That can be the reason that most epidemiological descriptions of HCV rely on seroprevalence studies [27]. Although it is present in up to $70 \%$ at onset of symptoms, the seroconversion can be detected by Elisa 20 weeks after exposure [28] which greatly affects the application of the necessary precautions. However, the rate of acute hepatitis C in Baghdad in 2010 was 1.6\% [22]. This difference can be attributed to the same causes mentioned previously in regard to the difference in the rate of acute hepatitis $B$.

In the current study, the prevalence rate of Anti HCV Ab in suspected patients in Baghdad was $(0.7 \%, 95 \% \mathrm{Cl}=0.09,2.5)$. Although the annual plan for viral hepatitis control and prevention includes strategies to prevent and control the transmission of HCV [22], however lack of a vaccine and post exposure prophylaxis [27] have a great negative impact on the control of its spread. The fact that previous history of blood transfusion was the most powerful predictor for positivity of Anti HCV Ab, indicates the need for the use of more accurate methods than the used methods (ELISA, RIBA) [29] in blood screening.

Likewise, previous history of tattooing or cupping was also considered a strong predictor of HCV infection which emphasize the need for application of strict sterilization techniques for invasive instruments and close monitoring of such practices.

\section{Conclusions}

Percentage of HBs Ag in patients with suspected acute viral hepatitis in Baghdad in 2010 was 3.3\% while that of Anti HCV Ab was $0.7 \%$.
Of the factors studied, the only factor that was associated with positive HBs Ag was age and considered the only predictor. Meanwhile, history of blood transfusion and previous tattooing or cupping were the most powerful predictors of Anti HCV positivity while controlling for all other risk factors.

\section{Recommendations}

Raising the awareness of health care providers about the importance of acute viral hepatitis in general. In addition to strict application of the scientific standard case definition in order to diagnose all the suspected of acute viral hepatitis according to type. Furthermore, improvement in the notification system to avoid over or under reporting of the cases, duplication, and discrepancies.

The relatively low rate of occurrence for Hepatitis B (3.3\%) underscores the importance of vaccination and efforts should be continued to ensure high coverage rate with particular emphasize on risk groups like health care staff, renal dialysis and blood diseases patients. Also, updated information about the new types of the vaccine should be taken into consideration and efforts should be spent on making them available. Moreover, the application of the strategies should be monitored closely and in collaboration with the peer units in Baghdad.

The low rate of Hepatitis C occurrence $(0.7 \%)$, unavailability of vaccine, and its long latency period should encourage the health staff to apply measures of Hepatitis C control strictly. The most important strategy is to use highly sensitive, specific and developed methods for blood screening. Special focus should be on the safe needle usage and disposal, sterilization of reusable surgical instruments, keeping personal care instruments personal, and raising the awareness about the importance of sterilizing the instruments used in tattooing and cupping.

\section{Competing interests}

The authors declare that they have no competing interests.

\section{Authors' contributions}

\begin{tabular}{|l|c|c|c|c|c|c|c|c|}
\hline $\begin{array}{l}\text { Authors' } \\
\text { contributions }\end{array}$ & HAK & AMT & ASAN & RWJ & OAM & SAK & NYH & AAD \\
\hline $\begin{array}{l}\text { Research concept } \\
\text { and design }\end{array}$ & $\checkmark$ & $\checkmark$ & -- & -- & - & -- & -- & -- \\
\hline $\begin{array}{l}\text { Collection and/or } \\
\text { assembly of data }\end{array}$ & $\checkmark$ & -- & -- & $\checkmark$ & $\checkmark$ & $\checkmark$ & $\checkmark$ & $\checkmark$ \\
\hline $\begin{array}{l}\text { Data analysis and } \\
\text { interpretation }\end{array}$ & -- & -- & $\checkmark$ & -- & -- & -- & -- & - \\
\hline Writing the article & $\checkmark$ & $\checkmark$ & -- & -- & -- & -- & -- & -- \\
\hline $\begin{array}{l}\text { Critical revision of } \\
\text { the article }\end{array}$ & -- & $\checkmark$ & $\checkmark$ & -- & -- & -- & -- & - \\
\hline $\begin{array}{l}\text { Final approval of } \\
\text { article }\end{array}$ & -- & -- & $\checkmark$ & -- & -- & -- & -- & - \\
\hline Statistical analysis & -- & -- & $\checkmark$ & -- & -- & -- & -- & - \\
\hline
\end{tabular}

Acknowledgement

In Loving Memory of Atallah Mekhlef Turky, a great boss, father, and leader, who had worked hard to establish a strong viral 
Khaleel et al. Epidemiology Reports 2013,

http://www.hoajonline.com/journals/pdf/2054-9911-1-1.pdf

doi: 10.7243/2054-9911-1-1

hepatitis program in Iraq. We would like to thank Ministry of Health, Baghdad, Iraq, for the morale and financial support. We would also like to express our deep gratitude to all who have participated.

Publication history

Received: 07-Oct-2013 Revised: 05-Nov-2013

Accepted: 23-Nov-2013 Published: 03-Dec-2013

\section{References}

1. Kuntz E and Kuntz HD. Hepatology textbook and atlas. Springer. 2008. | Book

2. National Center for Immunization and Respiratory Diseases, Centers for Disease Control and Prevention, Epidemiology and Prevention of Vaccine-Preventable Diseases, 12th ed. Atkinson W, Wolfe $C$ and Hamborsky J, Eds., Washington DC: Public Health Foundation. 2012. I Book

3. Thomas H, Lemon S and Zuckerman A. Viral Hepatitis, 3rd ed. Blackwell Publishing Ltd. 2005. I Book

4. Communicable Diseases Section, Public Health Group. The blue book: Guidelines for the control of infectious diseases. Melbourne Victoria: Communicable Diseases Section, Victorian Government Department of Human Services, 2005. I pdf

5. Institiute of Medicine. Hepatitis and liver cancer: a national strategy for prevention and control of hepatitis B and C. Washington, DC: The National Academies Press. 2010. I Pdf

6. Hu DJ, Bower WA and Ward JW. Viral hepatitis. in Atlas of sexually transmitted diseases and AIDS. Morse S, Moreland AA, Holmes KK Ed., London, Elsevier, 2010. 29.

7. Kim WR. Epidemiology of hepatitis B in the United States. Hepatology. 2009; 49:S28-34. | Article | PubMed Abstract | PubMed Full Text

8. DHHS. Combating the silent epidemic of viral hepatitis. 2010. | Pdf

9. Viral Hepatitis Section, Communicable Disease Control Center, Annual plan for viral hepatitis control and prevention,2010, Ministry of Health, Baghdad, Iraq, 2010.

10. Al-Naaimi AS, Turky AM, Khaleel HA, Jalil RW, Mekhlef OA, Kareem SA, Hasan NY and Dhadain AA. Predicting acute viral hepatitis serum markers ( $A$ and $E$ ) in patients with suspected acute viral hepatitis attending primary health care centers in Baghdad: a one year crosssectional study. Glob J Health Sci. 2012; 4:172-83. | Article | PubMed

11. Tarky AM, Akram W, Al-Naaimi AS and Omer AR. Epidemiology of viral hepatitis B and C in Iraq:a national survey 2005-2006. Zanco J. Med. Sci. 2013; 17:1.

12. Kamal SM, Mahmoud S, Hafez T and El-Fouly R. Viral hepatitis a to e in South mediterranean countries. Mediterr J Hematol Infect Dis. 2010; 2:e2010001. | Article | PubMed Abstract | PubMed Full Text

13. Ismail AM, Ziada HN, Sheashaa HA and Shehab El-Din AB. Decline of viral hepatitis prevalence among asymptomatic Egyptian blood donors: a glimmer of hope. Eur J Intern Med. 2009; 20:490-3. | Article | PubMed

14. Elzouki A, Esmeo MN, Samod M, Abonaja A, Alagi B and Daw M. Prevalence of hepatitis $B, C$ and HIV infection in Libya: a populationbased nationwide seroepidemiological study. J Gastroenterol Hepatol. 2006; 21: A114-A115. | Pdf

15. Ayed $Z$, Houinato $D$, Hocine $M$, Ranger-Rogez $S$ and Denis $F$. [Prevalence of serum markers of hepatitis $B$ and $C$ in blood donors and pregnant women in Algeria]. Bull Soc Pathol Exot. 1995; 88:225-8. | Article | PubMed

16. Boulaajaj K, Elomari Y, Elmaliki B, Madkouri B, Zaid D and Benchemsi N. [Prevalence of hepatitis $C$, hepatitis B and HIV infection among haemodialysis patients in Ibn-Rochd university hospital, Casablanca]. Nephrol Ther. 2005; 1:274-84. | Article | PubMed

17. Kafi-abad SA, Rezvan $\mathrm{H}$ and Abolghasemi $\mathrm{H}$. Trends in prevalence of hepatitis B virus infection among Iranian blood donors, 1998-2007. Transfus Med. 2009; 19:189-94. | Article | PubMed
18. Merat S, Rezvan H, Nouraie M, Jamali A, Assari S, Abolghasemi H, Radmard AR, Zaer-Rezaii H, Zeid-Abadi-Nejhad M, Hosseini MR, Amini-Kafiabad S, Maghsudlu M, Pourshams A and Malekzadeh R. The prevalence of hepatitis $B$ surface antigen and anti-hepatitis $B$ core antibody in Iran: a population-based study. Arch Iran Med. 2009; 12:225-31. | Pdf | PubMed

19. Mehmet D, Meliksah E, Serif Y, Gunay S, Tuncer O and Zeynep S. Prevalence of hepatitis $B$ infection in the southeastern region of Turkey: comparison of risk factors for HBV infection in rural and urban areas. Jpn J Infect Dis. 2005; 58:15-9. | Article | PubMed

20. Sarwar BM, Quraishi M, Mahmood CZ and Javaid K. Seroprevalence of hbsag and hcv antibodies in healthy individuals of high socioeconomic status. Biomedica. 2007; 23:3. I Pdf

21. Poustchi H, Sepanlou S, Esmaili S, Mehrabi N and Moghadam A. Hepatocellular Carcinoma in the World and the Middle East. Middle East Journal of Digestive Diseases. 2010; 2:1. | Pdf

22. Karim $M$ and Lahham H. Prevalence of viral hepatitis B and C in Syria. Syrian Epidemiological Bulletin. 2008; 2:3.

23. Viral Hepatitis Section, Ministry of health, Baghdad,Iraq. Communicable Disease Control Center, "Annual report of Viral Hepatitis," Not Published, 2010.

24. Ataallah TM, Hanan KA, Maysoun KS and Sadoon AA. Prevalence of hepatitis B and C among blood donors attending the National Blood Transfusion Center in Baghdad, Iraq from 2006-2009. Saudi Med J. 2011; 32:1046-50. | Pdf | PubMed

25. Daw MA and Dau AA. Hepatitis C virus in Arab world: a state of concern. ScientificWorldJournal. 2012; 2012:719494. | Article | PubMed Abstract I PubMed Full Text

26. Bener A, Al-Kaabi S, Derbala M, Al-Marri A and Rikabi A. The epidemiology of viral hepatitis in Qatar. Saudi J Kidney Dis Transpl. 2009; 20:300-6. | Article | PubMed

27. Madani TA. Hepatitis $C$ virus infections reported over 11 years of surveillance in Saudi Arabia. Trans R Soc Trop Med Hyg. 2009; 103:132-6. | Article | PubMed

28. Shepard CW, Finelli L and Alter MJ. Global epidemiology of hepatitis C virus infection. Lancet Infect Dis. 2005; 5:558-67. I Article | PubMed

29. Moses S. Hepatitis C Serology. 2013. | Website

30. National Blood Transfusion Center. Baghdad. 2010.

31. World Hepatitis Alliance Viral Hepatitis: Global Policy. London. 2010. | Wedsite

32. Hamilton BH, Paoloni JA and Chalabi H. Epidemiology of hepatitis B among professional male athletes in Qatar. Saudi Med J. 2010; 31:67883. | Pdf | PubMed

33. Merat $S$, Rezvan $H$, Nouraie $M$, Jamali A, Assari S, Abolghasemi $H$, Radmard AR, Zaer-Rezaii H, Zeid-Abadi-Nejhad M, Hosseini MR, Amini-Kafiabad S, Maghsudlu M, Pourshams A and Malekzadeh R. The prevalence of hepatitis $B$ surface antigen and anti-hepatitis B core antibody in Iran: a population-based study. Arch Iran Med. 2009; 12:225-31. | Pdf | PubMed

\section{Citation:}

Khaleel HA, Turky AM, Al-Naaimi AS, Jalil RW, Mekhlef OA, Kareem SA, Hasan NY and Dhadain AA. Prevalence of HBsAg and anti HCV Ab among patients with suspected acute viral hepatitis in baghdad, Iraq in 2010. Epidemiol Rep. 2014; 1:1. http://dx.doi.org/10.7243/2054-9911-1-1 